\title{
Los 40 años de la Convención Americana sobre Derechos Humanos a la luz de cierta jurisprudencia de la Corte Interamericana*
}

Este comentario, junto a los documentos que analiza, está disponible en www.anuariocdh.uchile.cl

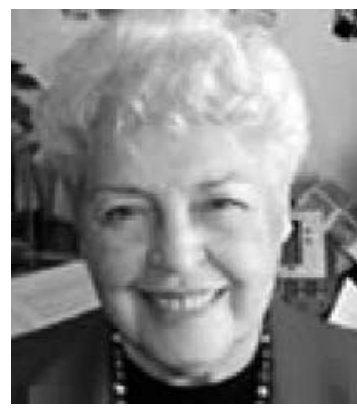

\section{Cecilia Medina Quiroga}

Co-Directora del Centro de Derechos Humanos. Abogada, Licenciada en Ciencias Jurídicas y Sociales por la Universidad de Chile, doctorada en Derecho en la Universidad de Utrecht, Holanda. Es profesora de Derecho Internacional de los Derechos Humanos de la Facultad de Derecho de la Universidad de Chile. Forma parte del Comité Académico y del Claustro del programa de doctorado de la Facultad de Derecho de la Universidad de Chile. Ha dictado cursos en el Instituto Interamericano de Derechos Humanos y ha sido profesora invitada en la Universidad de Lund, en el Instituto Internacional de Derechos Humanos de Estrasburgo, en el Instituto de Estudios Sociales de Ámsterdam, en la Facultad de Derecho de la Universidad de Toronto y en la Universidad para la Paz de las Naciones Unidas. Hizo docencia desde 1980 hasta 1993 en la Facultad de Derecho de la Universidad de Utrecht y ocupó la cátedra Robert F. Kennedy en la Facultad de Derecho de la Universidad de Harvard, en 1997. Desde su elección en 2002 se desempeña como Jueza de la Corte Interamericana de Derechos Humanos y actualmente es la Presidenta de la Corte. Durante ocho años fue miembro del Comité de Derechos Humanos de las Naciones Unidas y Presidenta del mismo en los años 1999 y 2000.

cmedina@derecho.uchile.cl

\section{RESUMEN}

El artículo analiza uno de los desarrollos más significativos de la jurisprudencia de la Corte Interamericana desde la entrada en vigencia de la Convención: su tratamiento de casos individuales insertos en un contexto de violaciones masivas y sistemáticas producidas por la represión estatal a causa de razones políticas. Particularmente, la autora reflexiona sobre la trascendencia de la labor de la Corte en la interpretación del contenido y alcance de la obligación de garantizar los derechos consagrados en la Convención, el acceso a la justicia para los familiares de las víctimas y la determinación de la condición de víctimas ante la Corte.

\section{Introducción}

La adopción de la Convención Americana sobre Derechos Humanos ${ }^{1}$ (en adelante la Convención o $\mathrm{CADH}$ ) fue un hecho histórico para el desarrollo de la institucionalidad del sistema de protección de los derechos humanos en el continente americano. Con anterioridad existía, en términos de instrumento, la Declaración Americana sobre los Derechos y Deberes del Hombre (Declaración Americana) adoptada en 1948 y, en términos de órganos, la Comisión Interamericana de Derechos Humanos (Comisión o CIDH) creada en 1959.

\footnotetext{
* La autora agradece a Mayra Cabral, visitante profesional de la Corte Interamericana de Derechos Humanos y a Oswaldo Ruiz y Oscar Parra, abogados de la misma Corte, por su ayuda en la búsqueda de jurisprudencia para este artículo.

1 Adoptada el 22 de noviembre de 1969 y entrada en vigencia el 16 de junio de 1978.
} 
La Convención estableció derechos humanos con un contenido definido y también detalladas obligaciones para los Estados, que fueron posteriormente desarrolladas por la ya existente Comisión Interamericana de Derechos Humanos y por la Corte Interamericana de Derechos Humanos, órgano nuevo creado en ese tratado, que entró en funciones en 1978. La Convención se diseñó, en una medida importante, siguiendo al Pacto Internacional de Derechos Civiles y Políticos y al Convenio Europeo sobre Derechos y Libertades Fundamentales, pero debió operar en un contexto político, social y económico muy diferente al europeo de los años 50 a 90.

En este trabajo quisiera examinar brevemente uno de los desarrollos más significativos de la jurisprudencia de la Corte Interamericana desde la entrada en vigencia de la Convención: su tratamiento de casos individuales insertos en un contexto de violaciones masivas y sistemáticas producidas por la represión estatal a causa de razones políticas. Se verán los desafíos con los que se ha enfrentado la Corte y cómo los ha resuelto y el impacto que estas soluciones han tenido en la región. Quedarán fuera temas tan importantes como las reparaciones y las medidas provisionales, ambas también producto de la amplia interpretación que la Corte ha dado a las normas de la Convención. Aun así, lo que sigue serán sólo un breve esbozo, pues un tratamiento más completo excede los márgenes de este ensayo.

Para realizar este examen es imprescindible referirse primero en general al sistema y a los desafíos que se plantearon a la Corte para adaptar su trabajo a la norma y a la realidad del continente.

\section{Los desafíos. El comienzo del sistema interamericano para la promoción y protección de los derechos humanos}

El derecho no se construye en el vacío ni desde la nada. Tampoco las organizaciones internacionales creadas conforme a él. Una organización internacional nace cuando existe un propósito común entre un grupo de Estados para solucionar problemas que trascienden sus fronteras. Por ello, las normas y disposiciones que la regulan se crean dentro de las circunstancias políticas, sociales y económicas existentes en esos Estados.

La Unión Panamericana -predecesora de la Organización de Estados Americanos (OEA)- no tenía, sin embargo, ese propósito común. Los Estados Unidos de Norteamérica deseaban proteger sus intereses económicos a través de normas regionales que crearan mecanismos pacíficos de solución de conflictos; los demás Estados pretendían consagrar en una norma internacional el principio de no intervención ${ }^{2}$. Cuando se adoptó la Carta de la OEA, los intereses de Estados Unidos se habían extendido de manera impresionante, más allá de Latinoamérica y, por lo tanto, la preocupación principal de los demás Estados era la de paliar, de algún modo, el desequilibrio económico entre estas dos partes del continente americano, puesto que ellos, después de la Segunda Guerra Mundial, dependían significativamente de Estados Unidos en materia económica. Por otra parte, ni Estados Unidos, ni Latinoamérica en su conjunto, poseían, además de estos objetivos, un interés real y genuino por los derechos humanos y por el perfeccionamiento de la incipiente democracia que existía en esa época ${ }^{3}$.

México, América Central y América del Sur constituían un conjunto de países con grandes diferencias económicas, sociales y políticas, con rígidas distinciones de clase, analfabetismo y con una sociedad discriminadora, inter alia, con los pobres (donde se encontraban abrumadoramente los indígenas) y con las mujeres. En aquellos países con una perversa inclinación hacia las

MEDINA, C. The Battle of Human Rights. Gross, Systematic Violation and The Inter-American System (The Battle). Holanda. Martinus Nijhoff, Dordrecht. 1988, pp. 21 y 22.

3 Ibídem, p. 30. 
dictaduras los derechos políticos y civiles no eran respetados y existían períodos de larga duración de violaciones masivas y sistemáticas del derecho a la vida, a la integridad y a cualquier otro que fuere necesario para que los detentadores del poder pudieran conservarlo ${ }^{4}$. No había tampoco una real cultura de derechos humanos siquiera en los países en que no existían dictaduras; las normas se aplicaban discriminatoriamente a mujeres, pobres, homosexuales e indígenas. Había finalmente una historia de autoritarismo estatal y social posible de observar hasta hoy.

En ese contexto se desarrolló el sistema. La Declaración Americana no cumplió papel alguno entre 1948 y 1959, fecha en que se creó la Comisión. Fue sólo una declaración más, de las que a menudo existen en el continente, a la que ningún Estado prestó atención. En 1959 se creó la Comisión Interamericana por resolución de una Reunión de Consulta de Ministros de Relaciones Exteriores celebrada en Chile, sin la base de un tratado, como un órgano encargado de "promover el respeto de tales derechos" ${ }^{\prime \prime}$.

Durante la discusión del proyecto de resolución que creaba la Comisión se generó oposición a éste pues no existía en el continente un tratado que estableciera obligaciones jurídicamente vinculantes para los Estados en materia de derechos humanos. La respuesta, que refleja la claridad de algunos Estados en la forma como se avanzaba en el continente, fue la del representante de Venezuela, quien declaró que no consideraba los argumentos técnicos y legales como un acercamiento apropiado al problema, agregando que "hay [en América] un ascenso democrático que se debe aprovechar para fortalecer todo aquello que sirva para hacer respetar los derechos humanos". El Canciller de Honduras lo apoyó, sosteniendo que el proyecto "significa una voz de aliento para la democracia americana" ${ }^{\prime}$. La esperanza de algunos Estados fue, pues, lo que creó el sistema y esa esperanza y el espíritu tras ella inspiró a la naciente Comisión y le imprimió el sello de su historia futura ${ }^{7}$.

El año 1959 las actividades de la Comisión se inauguraron con la represión política y las circunstancias en el Caribe, donde Fidel Castro había recién derrocado del poder, por la vía armada, a Fulgencio Batista; Trujillo reinaba en República Dominicana; y en el sur, en Paraguay, gobernaba Stroessner.

Las facultades de la Comisión no parecían muy prometedoras, pero su existencia fue percibida por aquellas víctimas de violaciones como su oportunidad para pedir amparo. La Comisión no las defraudó, tomando en sus manos la tarea de defenderlas. Quienes sufrían recurrían a ella a menudo sin asistencia jurídica, sin mayor habilidad para expresar lo que les pasaba y articular un relato coherente. Como la Comisión no tenía mayores trabas normativas -puesto que no existía un tratado y operaba básicamente con las normas de un reglamento que ella misma formulabaadaptó sus actividades a lo que la situación requería: investigaba, intervenía como mediadora o con buenos oficios, promovía soluciones amistosas, utilizaba la opinión pública para "movilizar

4 Entre 1959 y 1978 hubo numerosas dictaduras en el continente. Como ejemplos pueden citarse Rafael Leonidas Trujillo en República Dominicana (1930-1961); José María Lemus, producto de un golpe de Estado militar en El Salvador (19561960); Anastasio Somoza García (1937-1947 y 1950-1956) seguido por Luis Somoza Debayle (1956-1963), nombrado tras el asesinato de su padre; Alfredo Stroessner en Paraguay (1954-1989); Oswaldo López Arellano (1965-1974) en Honduras; François Duvalier, declarado Presidente vitalicio de Haití en 1964 y sucedido en esa misma calidad por su hijo, Jean-Claude Duvalier en 1971 y hasta 1986.

5 Quinta Reunión de Consulta de Ministros de Relaciones Exteriores (Santiago, 1959), Resolución VIII, párrafo II. Texto en Acta Final, Doc OEA/Ser.C/II.5, pp. 10-11.

6 Ibídem, pp. 225-229.

7 Las actividades de la Comisión Interamericana desde su establecimiento y hasta mediados de los años 80 pueden ser vistas en MEDINA, C. Op. Cit., capítulos IV, VIII, IX y X. Ver también VASAK, K. La Commission Interaméricaine des Droits de I'Homme, Bibliothèque Constitutionelle et de Science Politique, París, R. Pichon \& R. Durand-Auzias, 1968, Tomo XXXV; LEBLANC L. The OAS and the Promotion and Protection of Human Rights, La Haya, Martinus Nijhoff, 1977. 
la vergüenza", persuadía con amabilidad o con dureza. En suma, hacía todo lo que de un modo u otro podía ser cubierto por sus facultades para obtener algún logro, por pobre que éste fuera. La Comisión, por lo tanto, realizó en esa época tareas de una naturaleza altamente política, que fueron muchísimo más allá de la mera promoción de los derechos humanos ${ }^{8}$. Sus recursos humanos y financieros -siempre escasos- eran destinados a lidiar con situaciones donde el estado de derecho no existía o era extremadamente débil, desarrollando como mecanismo más importante informes sobre países que documentaban la situación general de derechos humanos ${ }^{9}$. Los Estados afectados, en general, no respondían a sus requerimientos, pero la ilusión de la Comisión era que, viniendo estos informes de un órgano establecido por los Estados, serían tomados en consideración por estos -en tanto organización colectiva-y a ello seguiría alguna forma de acción política. La ilusión fue vana. La Organización de Estados Americanos (OEA) no respondió, excepto en los casos de la Cuba de Fidel Castro y de Nicaragua en las postrimerías de la dictadura de Somoza, por razones que probablemente eran bastante ajenas a la preservación de los derechos humanos ${ }^{10}$.

La reticencia de los Estados para someterse a algún tipo de supervisión en materia de derechos humanos, visible en su silencio, se apreció también en la dificultad para adoptar un tratado con derechos y obligaciones jurídicamente vinculantes reforzadas con un órgano que tuviera jurisdicción sobre el tema. Los esfuerzos para elaborarlo empezaron en 1945 en la Conferencia Interamericana sobre los Problemas de la Guerra y de la Paz, que finalmente concluyeron con una Declaración ${ }^{11}$; en 1948 hubo otro intento, durante la Novena Conferencia Interamericana ${ }^{12}$, considerado prematuro en 1950 por el Comité Jurídico Interamericano ${ }^{13}$. En 1959, junto con la creación de la Comisión Interamericana de Derechos Humanos, la Quinta Reunión de Consulta de Ministros de Relaciones Exteriores decidió que el ambiente en el hemisferio era favorable y recomendó nuevamente al Comité Jurídico Interamericano que preparara un borrador de convención ${ }^{14}$. La elaboración de la Convención duró desde entonces hasta 1969 y su vigencia se dio sólo en 1978.

Todos estos antecedentes hacían presumir que no sería fácil que la Convención pudiera aplicarse a cabalidad en un tiempo razonable.

\section{La Corte Interamericana de Derechos Humanos}

La entrada en vigencia de la Convención Americana dio una base legal internacional a los derechos humanos de los individuos y a las obligaciones de los Estados y estableció dos órganos de control: la Comisión, que siguió siendo la misma de 1959, y la Corte Interamericana de Derechos Humanos. Esta última comenzó a operar en 1978, cuando la Convención entró en vigor.

Su composición da cuenta de su carácter jurisdiccional: siete jueces "elegidos a título personal entre juristas de la más alta autoridad moral, de reconocida competencia en materia de derechos humanos, que reúnan las condiciones requeridas para el ejercicio de las más elevadas funciones

8 Ibídem, capítulo VI. Ver también, MEDINA, C. The Role of Country reports in the Inter-American System of Human Rights. En: HARRIS D. J. y LIVINGSTONE, S. The Inter-American System of Human Rights, Oxford, Clarendon Press, 1998, pp. 115-132.

9 Ibídem, capítulo VI.

10 Ibídem, capítulos VIII y IX.

11 Conferencia Interamericana sobre los Problemas de la Guerra y de la Paz (Ciudad de México, 1945), Resolución XL.

12 Novena Conferencia Interamericana (Bogotá, 1948), Resolución XXXI.

13 Primera Reunión del Consejo Interamericano de Juristas (Río de Janeiro, 1950).

14 Quinta Reunión de Consulta, Op. Cit., nota 5, Resolución VIII, párrafo I. 
judiciales conforme a la ley del país del cual sean nacionales o del Estado que los proponga como candidatos" 15 .

La Corte tiene facultades de emitir opiniones consultivas y una jurisdicción contenciosa bajo la cual puede examinar casos individuales de presuntas violaciones de las normas de la Convención ${ }^{16}$. De acuerdo a la Convención, la Corte no puede ejercer ninguna de sus funciones de oficio. Para ejercer la competencia contenciosa requiere que un caso le sea sometido por la Comisión o por un Estado. Hasta ahora, sólo la Comisión ha presentado casos a la Corte. Para poder emitir una opinión consultiva necesita que un Estado miembro de la OEA o un órgano de la misma le hagan la consulta. Sin perjuicio de ello, dentro de sus limitaciones la Corte ha utilizado sus facultades para dirigir sus fallos y sus opiniones consultivas hacia un objetivo claro: el de interpretar las normas con el fin de lograr responder de manera adecuada a los problemas de derechos humanos de este continente.

La Convención es muy escueta en su tratamiento de la función contenciosa de la Corte. En primer lugar, los artículos 61 y 62 establecen algunos requisitos procesales para que esta función pueda ejercerse ${ }^{17}$ : no puede conocerse un caso a menos de que se hayan agotado los procedimientos ante la Comisión. Este reconocimiento puede hacerse incondicionalmente o bajo condición de reciprocidad, por un plazo determinado o para casos específicos. La mención de la reciprocidad obviamente sólo puede referirse a casos Ilevados ante la Corte por un Estado contra otro Estado. Sólo los Estados Partes que hayan reconocido la competencia contenciosa de la Corte pueden ser llevados ante ésta. Está reservado a los Estados y a la Comisión el derecho a presentar un caso a la Corte. Las víctimas no tienen locus standi.

En segundo lugar, la Convención se refiere a las sentencias de la Corte, diciendo que deben ser motivadas y que podrán tener votos disidentes. Añade que, si encuentra que exista una violación a la Convención la Corte:

"dispondrá que se garantice al lesionado en el goce de su derecho o libertad conculcados [...y] si ello fuera procedente, que se reparen las consecuencias de la medida o situación que ha configurado la vulneración de esos derechos y el pago de una justa indemnización a la parte lesionada"18.

El fallo de la Corte es definitivo e inapelable, sin perjuicio de que podrá pedirse una interpretación del mismo si su sentido o alcance no es claro para las partes ${ }^{19}$. El fallo es también de cumplimiento obligatorio ${ }^{20}$ y la parte de éste que disponga la indemnización "se podrá ejecutar en el respectivo país por el procedimiento interno vigente para la ejecución de sentencias contra el Estado". El interés que los Estados tienen en el mantenimiento del sistema obliga a la Corte a transmitir la sentencia a todos los Estados partes en la Convención ${ }^{21}$.

Finalmente, la Convención concede a la Corte la facultad de ordenar medidas provisionales en casos de extrema gravedad y urgencia, y cuando se haga necesario evitar daños irreparables a las personas. Esta facultad puede ejercerse aun respecto de casos que no hayan Ilegado a la Corte, a solicitud de la Comisión ${ }^{22}$.

\footnotetext{
$15 \mathrm{CADH}$, artículo 52.

CADH, artículos 33.b, y 61-64.

CADH, artículos 61 y 62.

$18 \mathrm{CADH}$, artículo 66.

19 CADH, artículo 67.

20 Me referiré a este punto más adelante.

$21 \mathrm{CADH}$, artículo 69.

$22 \mathrm{CADH}$, artículo 63.2
} 
La Corte debe aplicar la Convención de Viena sobre el Derecho de los Tratados de 23 de mayo de 1969 para resolver los problemas sobre reservas hechas por un Estado, así como utilizar la Declaración Americana u otros actos internacionales de la misma naturaleza para interpretar la Convención ${ }^{23}$. Tiene, además, competencia para conocer de los casos en que se aleguen violaciones de los derechos del párrafo a) del artículo 8 y artículo 13 del Protocolo Adicional a la Convención en materia de derechos económicos, sociales y culturales ${ }^{24}$; y de los casos en que se aleguen violaciones de la Convención Interamericana sobre Desaparición Forzada de Personas ${ }^{25}$. Finalmente, la Corte se ha atribuido competencia para aplicar la Convención Interamericana para Prevenir y Sancionar la Tortura ${ }^{26}$ y la Convención Interamericana para Prevenir, Erradicar y Sancionar la Violencia contra la Mujer ${ }^{27}$.

Aunque no tiene competencia para decidir sobre el cumplimiento de obligaciones que surjan de instrumentos ajenos a los ya señalados, son éstos una fuente de interpretación, para iluminar el contenido de las obligaciones que sí están bajo la jurisdicción de la Corte ${ }^{28}$.

El procedimiento de los casos contenciosos está regulado en detalle en el Reglamento de la Corte y no es mi intención desarrollarlo aquí ${ }^{29}$. Baste decir que en un comienzo se basaba en principio en la idea de que habría casos individuales que seguirían un procedimiento contradictorio entre, hasta hace poco, la Comisión y el Estado. La Corte, sin embargo, ha construido, a través de la modificación del Reglamento, un proceso más concordante con el hecho de que el afectado por las violaciones de derechos humanos es la persona. Aunque el individuo no tiene la capacidad de presentar su caso directamente ante este órgano, la Corte reglamentó su participación autónoma desde el momento en que el caso está presentado, con lo cual la legitimidad del procedimiento ha aumentado significativamente ${ }^{30}$. La Comisión, a su vez, muy poco tiempo después, enmendó también su Reglamento y decidió que el envío de casos a la Corte constituiría la norma general para la Comisión, necesitándose una decisión fundada de la mayoría absoluta de sus miembros para que el caso no se enviara ${ }^{31}$. Ambas enmiendas han tenido como resultado que en los últimos cinco años del Tribunal se ha resuelto el $62 \%$ de todos los casos contenciosos que la Corte ha conocido en sus treinta años de existencia ${ }^{32}$.

La función contenciosa de la Corte es, sin lugar a dudas, primordial para el sistema. Sus decisiones son obligatorias para el o los Estados que son parte de un proceso (hasta ahora no ha habido nunca más de un Estado) y constituyen la interpretación autorizada de las normas de la Convención.

$23 \mathrm{CADH}$, artículos 5 y 29.

24 Protocolo Adicional a la Convención Americana sobre Derechos Humanos en Materia de Derechos Económicos, Sociales y Culturales, "Protocolo de San Salvador", adoptado el 17 de noviembre de 1988, artículo 19.6.

25 Convención Interamericana sobre Desaparición Forzada de Personas, adoptada el 9 de junio de 1994, artículo XIII.

26 Corte IDH. Caso de los "Niños de la Calle" (Villagrán Morales y otros) Vs. Guatemala. Fondo. Sentencia de 19 de noviembre de 1999. Serie C Nº 63, párrs. 239 a 252.

27 Corte IDH. Caso del Penal Miguel Castro Castro Vs. Perú. Fondo, Reparaciones y Costas. Sentencia de 25 de noviembre de 2006. Serie C N 160 .

28 Sobre este tema, ver Corte IDH. Caso de los "Niños de la Calle" (Villagrán Morales y otros) Vs. Guatemala. Sentencia de 19 de noviembre de 1999. Reparaciones, Serie C No 63 y Caso "Instituto de Reeducación del Menor" Vs. Paraguay. Excepciones Preliminares, Fondo, Reparaciones y Costas. Sentencia de 2 de septiembre de 2004. Serie C No 112.

29 Para un examen detallado de la parte procesal de la Comisión y de la Corte, ver FAÚNDEZ, H. El sistema interamericano de protección de los derechos humanos. Aspectos institucionales y procesales. Tercera Edición puesta al día. Costa Rica. IIDH, 2004, p. 1049.

30 Corte IDH. Reglamento modificado en 2000, artículo 23. Texto en www.corteidh.or.cr. La Corte y la Comisión están actualmente, junio de 2009, realizando una reforma profunda a cada uno de sus Reglamentos que, inter alia, cambiará el rol de la Comisión en los casos individuales.

$31 \mathrm{CIDH}$, Reglamento actual, artículo 44.1.

32 Ver Corte IDH. Informe Anual 2008, en http://www.corteidh.or.cr 
La introducción de un órgano jurisdiccional en un mecanismo que hasta ese momento había sido altamente flexible y político, más la situación política del momento y el legado de situaciones anteriores en el continente, marcaron fuertemente la manera en que la Corte desarrolló su jurisprudencia. Su cometido era la interpretación auténtica de la Convención y la supervisión del cumplimiento de las obligaciones internacionales de los Estados Partes con el fin de decidir si con su conducta algún Estado había violado la Convención en perjuicio de algún ser humano. Para esto último era imposible ignorar ni el presente ni el pasado del sistema y del continente.

Los avances más notables de la Corte han sido, sin duda, los que se han logrado a través del ejercicio de su jurisdicción contenciosa, a pesar de que, sobre todo en un comienzo, operó en circunstancias que podrían calificarse de adversas. Aparte de la posible incertidumbre de la Corte sobre cómo reaccionarían los Estados enfrentados a una sentencia adversa a ellos, existía el problema de que los casos que se discutían ante la Comisión trataban sobre violaciones específicas pero dentro de un cuadro de violaciones masivas y sistemáticas ${ }^{33}$; las normas de la Convención no parecían haber tenido esto en cuenta, siendo esta situación, además, un campo completamente inexplorado por los órganos jurisdiccionales de derechos humanos.

La Corte, sin embargo, tenía como norte lograr que su existencia constituyera un avance para los derechos humanos de la región y eso implicaba discurrir los modos en que podía hacer frente a estos desafíos. Toda su jurisprudencia tiene las huellas de esa empresa.

\section{Los logros}

Es imposible aquí hacer un estudio acabado de la forma como la Corte enfrentó esos desafíos, por lo que he elegido un tema: la manera como la Corte solucionó el problema de aplicar un procedimiento destinado a casos individuales a violaciones que formaban parte de una práctica estatal cuando había ausencia de Estado de Derecho, es decir, de violaciones por razones políticas. Los aspectos del tema que trataré aquí tienen que ver con el desarrollo del concepto de la obligación de garantizar; el tratamiento de las violaciones a víctimas por tener relación con otra víctima de esa práctica (que se conoce como el problema de "los familiares"), ligado estrechamente al "derecho a la verdad", para terminar con el impacto de los fallos de la Corte en la región. Para ello usaré como leading case el caso de Velásquez vs. Honduras ${ }^{34}$, sobre una desaparición forzada ocurrida en Honduras en 1981.

\section{a. La obligación de garantizar}

El artículo 1 de la Convención Americana dispone que:

Los Estados Partes en esta Convención se comprometen a respetar los derechos y libertades reconocidos en ella y a garantizar su libre y pleno ejercicio a toda persona que esté sujeta a su jurisdicción, sin discriminación alguna por motivos de raza, color, sexo, idioma, religión, opiniones políticas o de cualquier otra índole, origen nacional o social, posición económica, nacimiento o cualquier otra condición social.

\footnotetext{
33 Aunque la evolución del derecho internacional de los derechos humanos permitiría formular hoy una definición más comprensiva del concepto "violaciones masivas y sistemáticas", en este trabajo utilizaré la definición que propuse en 1988 en mi libro "The Battle": las violaciones masivas y sistemáticas son aquellas violaciones que sirven de instrumento para el logro de las políticas gubernamentales, perpetradas en tal cantidad y de tal manera como para crear una situación en que los derechos a la vida, a la integridad personal o a la libertad personal de la población de un Estado, como un todo o uno o más sectores de ella, se ven continuamente infringidos o amenazados. (Ver, MEDINA, C. The Battle, nota 2, capítulo II y, en particular, p. 16).

34 Corte IDH. Caso Velásquez Rodríguez Vs. Honduras. Fondo. Sentencia de 29 de julio de 1988. Serie C N 4.
} 
La obligación de respetar es entendida como el deber de los agentes del Estado de no violar ellos los derechos humanos. La de garantizar, por el contrario, requiere algo más. Se garantiza el libre y pleno ejercicio de los derechos, y para ello es imprescindible que el Estado emprenda acciones que hagan posible este ejercicio. La Corte Interamericana de Derechos Humanos analizó exhaustivamente el contenido de esta obligación en el caso Velásquez Rodríguez, que trataba de una desaparición en Honduras en un contexto de violaciones masivas y sistemáticas perpetradas en la época, estableciendo que ella "implica el deber de los Estados partes de organizar todo el aparato gubernamental y, en general, todas las estructuras a través de las cuales se manifiesta el ejercicio del poder público, de manera tal que sean capaces de asegurar jurídicamente el libre y pleno ejercicio de los derechos humanos". La consecuencia de esto es que "los Estados deben prevenir, investigar y sancionar toda violación de los derechos reconocidos por la Convención y procurar, además, el restablecimiento, si es posible, del derecho conculcado y, en su caso, la reparación de los daños producidos por la violación de los derechos humanos" ${ }^{\prime 35}$.

Esta acción del Estado no debe ser sólo formal. Al respecto, la Corte añadió que para cumplir con esta obligación se requería una conducta activa no sólo del órgano legislativo ${ }^{36}$. Su responsabilidad, por lo tanto, se genera cuando se ha perpetrado una violación con el apoyo o tolerancia del poder público o en defecto de toda prevención o impunemente ${ }^{37}$, siendo irrelevante si el autor directo es un agente del Estado o un particular ${ }^{38}$.

Las bases de gran parte del desarrollo de la jurisprudencia de la Corte se asentaron en este caso. Su mayor aporte fue precisamente la elaboración del contenido de la obligación de garantizar. Como éste era un caso de una desaparición forzada, el primer paso de la Corte fue caracterizar este fenómeno -acaecido dentro de un contexto de violaciones masivas y sistemáticas- como una violación severa de tres derechos de la Convención: vida, integridad personal y libertad personal. La desaparición forzada sería la más severa de todas las violaciones, ya que afecta no sólo al desaparecido sino que a sus familiares cercanos que sufren el calvario de la incertidumbre de la suerte que éste ha tenido y se enfrentan con un muro de silencio de los órganos del Estado. Es evidente que estas características influyeron en la Corte para aplicar el derecho en la forma más amplia posible, haciendo una interpretación extensiva de las normas.

De la obligación de garantizar se desprendió el deber de prevenir, cuyo elemento principal era el de tomar "todas aquellas medidas de carácter jurídico, político, administrativo y cultural que promuevan la salvaguarda de los derechos humanos", poniendo como ejemplo de una falta de prevención el haber puesto al señor Velásquez bajo las manos de "cuerpos represivos oficiales que impunemente practiquen la tortura y el asesinato" ${ }^{\prime 39}$. De aquí se desprende que forma parte de la obligación de garantizar la de "proteger" a una persona que está en evidente peligro. Una de las más importantes contribuciones del caso Velásquez es la manera como se utilizó la obligación de prevenir para atribuir responsabilidad a un Estado de una violación específica, pero llevada a cabo en un contexto de violaciones masivas y sistemáticas. El fenómeno de las desapariciones se caracteriza por un empeño y una diligencia admirables para borrar toda huella de su cometimiento: se priva de la libertad a una persona, generalmente de manera ilegal y arbitraria y habitualmente por agentes del Estado; se niega por los agentes del Estado esta privación; el Estado rehúsa investigar la desaparición u obstaculiza esta investigación a fin de que pasen los años y la acción penal o

35 Ibídem, párr. 166.

36 Ibídem, párr. 167.

37 Ibídem, párrs. 173 y 174.

38 Ibídem, párr. 147.

39 Corte IDH. Caso Velásquez Rodríguez Vs. Honduras, párr. 175. 
la pena prescriban. Estas características enfrentan al órgano jurisdiccional internacional con la dificultad primera de establecer el hecho de que alguien haya desaparecido de manera forzada y, después, con el problema de atribuir al Estado la responsabilidad por esa desaparición ${ }^{40}$.

De la obligación de garantizar emergió asimismo el deber de investigar, procesar y condenar, calificada por la Corte como una obligación de medio y no de resultado, en razón de que ciertas circunstancias -el transcurso del tiempo, la desaparición de los testigos, el temor de los testigos u otras $^{41}$ - pueden hacer muy difícil la investigación. Sin embargo, se enfatizó que la investigación debe ser seria, y asumida por el Estado como un deber jurídico propio, no dependiente de la iniciativa de los particulares presuntamente afectados y debe llevarse a cabo, sea que los presuntos responsables sean agentes del Estado o particulares; en este ultimo caso, la falta de investigación se transforma en un auxilio del poder público a la violación del particular, lo que compromete la responsabilidad del Estado ${ }^{42}$, como había sucedido en el caso Velásquez. Tampoco el Ejecutivo había hecho una investigación seria, a pesar de las denuncias públicas y de los requerimientos de la Comisión Interamericana para que el Estado diera información sobre lo sucedido ${ }^{43}$. Finalmente, se había solicitado a los familiares que aportaran pruebas concluyentes al expediente, en vez de proceder a investigar el caso de oficio, por un órgano imparcial. Todo esto constituía una violación del artículo 1.1 de la Convención. La sentencia no examinó la investigación interna aplicando parámetros de la Convención, como lo ha hecho posteriormente, sino que se limitó a decidir que los hechos descritos constituían una infracción al deber de garantizar establecido en el artículo 1.1. de la Convención en detrimento de la persona desaparecida.

En el caso Velásquez, Ilegado a la Corte desde la Comisión, se había aplicado por ésta la argumentación de que estaba demostrado que existía en Honduras, a la fecha de desaparición del señor Velásquez, una política de desapariciones auspiciada o tolerada por el Estado con un cierto patrón. Luego, era posible probar, mediante prueba circunstancial o indirecta, o ambas, o por inferencias lógicas pertinentes, que Velásquez también había desaparecido. La Corte aceptó esta argumentación ${ }^{44}$. La prueba de la práctica se realizó ante la Corte por declaraciones de testigos, entre ellos personas que habían logrado reaparecer, documentos y recortes de prensa que daban cuenta de hechos públicos y notorios ${ }^{45}$, logrando construir un cuadro del patrón que se daba en las desapariciones $^{46}$. La Corte llegó también a la convicción de que se había probado la desaparición de Velásquez y que ella correspondía "al marco de la práctica de desapariciones a que se refieren los hechos que se consideran probados en los literales a) a d) inclusive [del párrafo 147]"47. A pesar de esto -y aquí está la mayor relevancia de la sentencia en este punto- se sostuvo que:

182. La Corte tiene la convicción, y así lo ha dado por probado, de que la desaparición de Manfredo Velásquez fue consumada por agentes que actuaron bajo la cobertura de una función pública. Pero, aunque no hubiera podido demostrarse tal cosa, la circunstancia de que el aparato del Estado se

40 Ibídem, párr. 160

41 No hay que olvidar que durante el caso Velásquez un testigo fue asesinado. Caso Velásquez Rodríguez Vs. Honduras, párr. 40.

42 Ibídem, párr. 177. Esto se ha repetido de manera permanente. Ver, por ejemplo, Corte IDH. Caso Cesti Hurtado. Sentencia de 31 de mayo de 2001. Reparaciones, Serie C No 56, párr. 62; Caso Villagrán Morales y otro. Sentencia de 19 de noviembre de 1999. Reparaciones, Serie C No 63, párr. 100; y Caso de la "Panel Blanca" (Paniagua Morales y otros) Vs. Guatemala. Fondo. Sentencia de 8 de marzo de 1998. Serie C No 37, párr. 100.

43 Ver Caso Velásquez, párrs. 179-180.

44 Ibídem, párrs. 124 y 126.

45 Ibídem, párr. 119.

46 Ibídem, párr. 147.b y d.

47 Ibídem, párr. 147.g. 
haya abstenido de actuar, lo que está plenamente comprobado, representa un incumplimiento imputable a Honduras de los deberes contraídos en virtud del artículo 1.1 de la Convención, según el cual estaba obligada a garantizar a Manfredo Velásquez el pleno y libre ejercicio de sus derecho humanos.

Con esto, la Corte evitó la necesidad de probar la acción u omisión particular del Estado en un caso específico sino que atribuyó al Estado responsabilidad internacional por no haber actuado preventivamente, puesto que existía un sinnúmero de casos que demostraban el patrón sistemático.

Esta construcción argumentativa se ha usado no sólo en este tipo de casos. Las mujeres han empezado a utilizarla, por ejemplo, para sostener la responsabilidad del Estado en casos particulares por no reaccionar ante la situación general de violencia doméstica que existe en tantos países de la región ${ }^{48}$.

En cuanto a las reparaciones -también un elemento del deber de garantizar- la víctima de las violaciones fue don Manfredo Velásquez, la persona desaparecida, pero sin embargo la Corte ordenó en la parte resolutiva de su sentencia que "Honduras está obligada a pagar una justa indemnización compensatoria a los familiares de la víctima" ${ }^{49}$, personas que se habían hecho acreedoras a una reparación por el inmenso sufrimiento que la desaparición del señor Velásquez les había hecho padecer, pero no ordenó que se investigaran los hechos y que se procesara y condenara a los culpables. En la etapa de reparaciones, que siguió a la sentencia de fondo, la Comisión y los representantes de la víctima pidieron a la Corte que dispusiera que el Estado debía cumplir con esta obligación y el Estado se opuso por no existir una orden en el fallo mismo. La Corte, sin embargo, utilizó el texto de la sentencia donde se establecía la subsistencia de la obligación de investigar mientras se mantenga la incertidumbre sobre la suerte final del desaparecido ${ }^{50}$ y el deber de prevenir ${ }^{51}$ y sostuvo que "es un principio del derecho procesal que los fundamentos de una decisión judicial forman parte de la misma. La Corte declaró, en consecuencia, que tales obligaciones a cargo de Honduras subsistían hasta su total cumplimiento" ${ }^{\prime 2}$. Nada se dijo sobre el derecho de los familiares de conminar al Estado a llevar a cabo esta investigación.

Las reparaciones, tema que no se tratará, han evolucionado muchísimo a través de la jurisprudenciade la Corte, la que constituye, en mi opinión, una actividad pionera de este sistema.

\section{b. Desarrollo de la jurisprudencia sentada por el caso Velásquez}

Con el curso de los años, la Corte ha refinado la formulación de la obligación de investigar. Desde la amplísima formulación de la sentencia en Velásquez -la obligación de los Estados de prevenir, investigar y sancionar toda violación de los derechos reconocidos por la Convención ${ }^{53}$ - ha Ile-

48 Ver, CIDH, Caso Maria da Penha Mahia Fernandes c. Brasil, Caso 12.051, Informe No 54/01 de 16 de abril de 2001.

Corte IDH. Caso Velásquez Rodríguez, párr. 194.5.

50 Ibídem, párr. 181.

51 Ibídem, párr. 174.

52 Corte IDH. Caso Velásquez Rodríguez Vs. Honduras. Reparaciones y Costas. Sentencia de 21 de julio de 1989. Serie C $\mathrm{N}^{\circ} 7$, párrs. 34 y 35

53 Esto fue repetido en muchos casos. Ver, por ejemplo, Corte IDH. Caso Caballero Delgado y Santana vs. Colombia, Sentencia de 8 de diciembre de 1995. Fondo. Serie C № 22, párrs. 58, 69 y punto resolutivo 5; Caso El Amparo vs. Venezuela. Sentencia de 14 de septiembre de 1996. Reparaciones. Serie C No 28, párr. 61 y punto resolutivo 4; Caso Neira Alegría y otros vs. Perú, Sentencia de 19 de septiembre de 1996 Reparaciones. Serie C No 29, párr. 69 y punto resolutivo 4; Caso Castillo Páez vs. Perú, Sentencia de 3 de noviembre de 1997. Fondo. Serie C No 34, párr. 90; Caso Suárez Rosero vs. Ecuador, Sentencia de 12 de noviembre de 1997. Fondo. Serie C No 35, párr. 107 y punto resolutivo 6; Caso Blake vs. Guatemala, Sentencia de 24 de enero de 1998. Fondo. Serie C No 36, párr. 121 y punto resolutivo 3; Caso Morales y otros vs. Guatemala, párr. 178 y punto resolutivo 6. 
gado ahora a sostener, de una manera que guarda consecuencia, que la obligación procede sólo para cierto tipo de violaciones ${ }^{54}$. Con respecto al derecho a la vida, por ejemplo, ha sostenido que siempre se aplica en los casos de desapariciones forzadas ${ }^{55}$, de ejecuciones sumarias ${ }^{56}$ y de privación de la vida por uso excesivo de la fuerza ${ }^{57}$. Respecto de esto último, la Corte ha citado a la Corte Europea que señaló en algunos casos fallados por ella ${ }^{58}$ que era necesaria la existencia de un procedimiento en el que se revisara la legalidad del uso de la fuerza letal por parte de dichas autoridades ${ }^{59}$. La Corte ha establecido, además, que la obligación de investigar es exigible cuando ha habido violaciones a la integridad personal, sin especificar en todas las ocasiones si se trata de torturas o de otros tratos crueles, inhumanos o degradantes, aun cuando la violación no se produzca en el contexto de una situación clásica de violaciones masivas y sistemáticas. A menudo se trata de torturas o malos tratos sufridos dentro de la cárcel, en cuyo caso se exige también investigar los hechos de la privación ilegal o arbitraria de la libertad personal ${ }^{60}$.

La obligación de investigar y la de prevenir normalmente se confunden. Así, la Corte ha incluido como medidas de prevención (i) la persecución penal, que considera "una vía fundamental para prevenir futuras violaciones de derechos humanos" ${ }^{\prime 1}$, y (ii) la investigación para conocer la verdad de lo ocurrido en estos casos, puesto que "el conocer la verdad facilita a la sociedad peruana la búsqueda de formas de prevenir este tipo de violaciones en el futuro" ${ }^{62}$. Esta es también una jurisprudencia constante de la Corte $^{63}$.

Íntimamente ligado con la obligación de investigar y sancionar ciertas violaciones de derechos humanos aparece el tema de la impunidad. La obligación de investigar, como se dijo en Velásquez, subsiste mientras se mantenga la incertidumbre sobre la suerte final del desaparecido. Por lo tanto, es claro que la impunidad es incompatible con ella. La Corte definió la impunidad en 1998 en el caso Paniagua Morales, un caso de secuestro, tortura y asesinato, como "la falta en su conjunto

54 En el caso de la Masacre de la Rochela, la Corte sostuvo que "[e]n casos de graves violaciones a los derechos humanos, las obligaciones positivas inherentes al derecho a la verdad exigen la adopción de los diseños institucionales que permitan que este derecho se realice en la forma más idónea, participativa y completa posible y no enfrente obstáculos legales o prácticos que lo hagan ilusorio" (mi énfasis). Ver Corte IDH, Caso de la Masacre de La Rochela vs. Colombia, Sentencia de 11 de mayo de 2007, Fondo Reparaciones y Costas, Serie C No 163, párr. 195.

55 Una de las últimas sentencias es la del Caso Heliodoro Portugal vs. Panamá, Excepciones Preliminares. Fondo Reparaciones y Costas, sentencia de 12 de agosto de 2008, Serie C No 186, párrs. 243-247.

56 Corte IDH. Caso Myrna Mack vs. Guatemala. Sentencia de 25 de noviembre de 2003. Serie C No 101, párr. 156; Caso de la Masacre de La Rochela, párr. 195; Caso Valle Jaramillo vs. Colombia. Sentencia de 27 de noviembre de 2008. Serie C No 192, párrs. 232-233.

57 Corte IDH. Caso Hermanos Gómez Paquiyauri vs. Perú. Sentencia de 8 de julio de 2004. Fondo Reparaciones y Costas. Serie C No 110, para 131; Caso Myrna Mack Chang, párr. 157; y Caso Juan Humberto Sánchez vs. Honduras. Sentencia de 7 de junio de 2003. Serie C No 99, párr. 112.

58 Eur. Court H.R., Case of Hugh Jordan v. the United Kingdom judgment of 4 May 2001, párr. 105; Case of Çiçek v. Turkey judgment of 27 February 2001, párr. 148; y McCann and Others v. the United Kingdom judgment of 27 September 1995 , Series A No 324, párr. 161.

59 Corte IDH. Caso Myrna Mack, párr. 157.

60 Ver, por ejemplo, Corte IDH. Caso Gutiérrez Soler vs. Colombia. Sentencia de 12 de septiembre de 2005. Fondo y Reparaciones, párrs. 95, 96; Caso Tibi vs. Ecuador. Sentencia de 7 de septiembre de 2004. Serie C № 114, párrs. 255, 258-259, donde ordena investigar también la detención ilegal del señor Tibi.

61 Corte IDH. Caso Goiburú vs. Paraguay, Fondo. Reparaciones y Costas. Sentencia de 22 de septiembre de 2006, Serie C № 153, párr. 92.

62 Corte IDH. Caso Gómez Palomino Vs. Perú. Fondo, Reparaciones y Costas. Sentencia de 22 de noviembre de 2005. Serie C No 136, párr. 78.

63 Corte IDH. Caso de la "Masacre de Mapiripán" Vs. Colombia. Fondo, Reparaciones y Costas. Sentencia de 15 de septiembre de 2005. Serie C No 134, párr. 162. 
de investigación, persecución, captura, enjuiciamiento y condena de los responsables de las violaciones de los derechos protegidos por la Convención Americana" ${ }^{64}$.

Hay diversas formas en que se puede llegar a la impunidad y la Corte las ha condenado todas, declarándolas incompatibles con la Convención Americana. Una es la pasividad del tribunal al que corresponde conocer de un caso de presunta violación al derecho a la vida ${ }^{65}$. Otra es la dictación de leyes de amnistía, declaradas ya por la Comisión Interamericana como violatorias del artículo 1 -que consagra las obligaciones de respetar y garantizar los derechos de la Convención ${ }^{66}$. Una tercera es la aplicación a estos casos de disposiciones de prescripción y el establecimiento de excluyentes de responsabilidad que pretendan "impedir la investigación y sanción de los responsables de las violaciones graves de los derechos humanos tales como [...] las ejecuciones sumarias, extralegales o arbitrarias y las desapariciones forzadas, todas ellas prohibidas por contravenir derechos inderogables reconocidos por el Derecho Internacional de los Derechos Humanos" ${ }^{\prime \prime}$.

El concepto de prescripción ha sido refinado por la Corte, ajustándolo también a la idea de que no toda violación de derechos humanos es imprescriptible. Así, sostuvo que: "la prescripción de la acción penal es inadmisible e inaplicable cuando se trata de muy graves violaciones de los derechos humanos en los términos del Derecho Internacional. La jurisprudencia constante y uniforme de la Corte así lo ha señalado" (mi énfasis) ${ }^{68}$.

Elaborar sobre estos temas ha llevado también a la Corte a decidir que el principio de cosa juzgada implica la intangibilidad de una sentencia sólo cuando se llega a ésta respetándose el debido proceso de acuerdo a la jurisprudencia de este Tribunal en la materia, lo que permite a la Corte decidir que una condena penal, por ejemplo, no es válida en razón de no haber cumplido con los requisitos del artículo 8 de la Convención ${ }^{69}$.

Como es posible advertir, en todos estos ejemplos citados la jurisprudencia de la Corte ha servido para dar una respuesta jurisdiccional a casos que habían permanecido en la impunidad por muchos años y traer algún tipo de satisfacción a aquéllos que habían presenciado con impotencia la falta de respuesta estatal a sus demandas de justicia. Asimismo, no parece haber duda de que una de las razones que ha habido para elaborar con tanta intensidad esta obligación obedece al hecho de que una cantidad significativa de casos llegados a la Corte se refieren a estas violaciones que no han sido investigadas por el órgano judicial, órgano cuyas falencias se ven a menudo en todo nuestro continente. Hasta la fecha, ha habido 27 casos de violación de los artículos 4 y 5 por falta de respuesta judicial interna o por una respuesta insuficiente y 29 casos del mismo tipo en

64 Corte IDH. Caso de la "Panel Blanca" (Paniagua Morales y otros) Vs. Guatemala, párr. 173.

65 Corte IDH. Caso Bulacio Vs. Argentina. Fondo, Reparaciones y Costas. Sentencia de 18 de septiembre de 2003. Serie C № 100, párr. 119; Caso Myrna Mack Chang Vs. Guatemala. Fondo, Reparaciones y Costas. Sentencia de 25 de noviembre de 2003. Serie C No 101, párr. 210.

66 CIDH. Caso caducidad de la pretensión punitiva del Estado (Uruguay), Nos. 10029, 10036, 10145, 10305, 10372, 10373, 10374, 10375, resolución 29/92, de 2 de octubre de 1992 en Informe Anual de la Comisión Interamericana de Derechos Humanos 1992-93 y CIDH, Casos No 10147, 10181, 10240, 10262, 10309 y 10311 (Argentina), Resolución 28/92 de 2 de octubre de 1992 en Informe Anual de la Comisión Interamericana de Derechos Humanos 1992-93.

67 Corte IDH. Caso Barrios Altos Vs. Perú. Fondo. Sentencia de 14 de marzo de 2001. Serie C No 75, párrs. 41 a 43; Caso La Cantuta vs. Perú. Sentencia de 29 de noviembre de 2006, Serie C No 162, párr. 152; Caso Almonacid Arellano y otros, Sentencia de 26 de septiembre de 2006. Fondo, Reparaciones y Costas. Serie C No 16, párr. 112; y Caso de las Masacres de Ituango, párr. 402.

68 Corte IDH. Caso Albán Cornejo y otros. Vs. Ecuador. Fondo, Reparaciones y Costas. Sentencia de 22 de noviembre de 2007. Serie C N 171 .

69 Corte IDH. Caso Almonacid Arellano y otros, párr. 154. 
que los Estados han reconocido sus responsabilidad, pero que han culminado con una sentencia de la Corte en que decide que se cumpla con la obligación de investigar.

Además de esto, la Corte ha utilizado la obligación de garantizar en casos muy diversos a los examinados que no serán objeto de estudio en este artículo. Se han dictado sentencias sobre la propiedad colectiva de los pueblos indígenas ${ }^{70}$. En el caso Awas Tingni, la Corte interpretó el artículo 21 de la Convención enfatizando que lo que éste protegía era "el uso y goce" de los bienes de las personas y no la "propiedad privada"; seguidamente señaló que los términos de un tratado tienen sentido autónomo, que su interpretación debe ser evolutiva y que se debe tener en consideración que los indígenas poseen "una tradición comunitaria sobre una forma comunal de la propiedad colectiva de la tierra", para concluir que "el artículo 21 de la Convención protege el derecho a la propiedad en un sentido que comprende, entre otros, los derechos de los miembros de las comunidades indígenas en el marco de la propiedad comunal, la cual también está reconocida en la Constitución Política de Nicaragua"71. Otras se han referido a las limitaciones a la libertad de expresión ${ }^{72}$ y al contenido de ese derecho para incluir allí el derecho de acceso a la información ${ }^{73}$. Se ha utilizado, entre otras cosas, para proteger los derechos de los niños ${ }^{74}$, de los discapacitados mentales ${ }^{75}$, dando también orientaciones para la responsabilidad del Estado sobre los órganos privados de salud ${ }^{76}$. Estos fallos han ordenado a los Estados el emprendimiento de una serie de acciones para cumplir con la obligación de garantizar. En suma, esta jurisprudencia ha excedido con creces el propósito primero con el que empezó a desarrollarse y ha significado un importante avance para el goce de los derechos humanos.

\section{c. La introducción de otras violaciones en relación con las desapariciones, ejecuciones sumarias y otras violaciones de ese tipo. Los artículos 8 y 25}

El fenómeno de las desapariciones generó otro problema para la Corte. El fallo de la Corte normalmente establece una violación en perjuicio de una o más personas determinadas. En el caso Genie Lacayo, la muerte de un menor a manos de militares nicaragüenses, acaecida antes de que el Estado hubiera reconocido la jurisdicción contenciosa de la Corte, ésta se vio inhibida en su competencia ratione temporis para conocer de la violación del derecho a la vida ni pudo declarar

70 Corte IDH. Caso de la Comunidad Mayagna (Sumo) Awas Tingni Vs. Nicaragua. Fondo, Reparaciones y Costas. Sentencia de 31 de agosto de 2001. Serie C No 79; Caso de la Comunidad Moiwana Vs. Surinam. Excepciones Preliminares, Fondo, Reparaciones y Costas. Sentencia 15 de junio de 2005. Serie C № 124; Caso Comunidad Indígena Yakye Axa Vs. Paraguay. Fondo Reparaciones y Costas. Sentencia 17 de junio de 2005. Serie C No 125; Caso Comunidad Indígena Sawhoyamaxa Vs. Paraguay. Fondo, Reparaciones y Costas. Sentencia de 29 de marzo de 2006. Serie C No 146; Caso del Pueblo Saramaka. Vs. Surinam. Excepciones Preliminares, Fondo, Reparaciones y Costas. Sentencia de 28 de noviembre de 2007. Serie C N 172 .

71 Ver Caso Awas Tingni, párrs. 142-149.

72 Corte IDH. Caso "La Última Tentación de Cristo" (Olmedo Bustos y otros) Vs. Chile. Fondo, Reparaciones y Costas. Sentencia de 5 de febrero de 2001. Serie C No 73; Caso Herrera Ulloa Vs. Costa Rica. Excepciones Preliminares, Fondo, Reparaciones y Costas. Sentencia de 2 de julio de 2004. Serie C No 107; Caso Canese vs. Paraguay. Sentencia de 31 de agosto de 2004. Fondo, reparaciones y Costas. Serie C No 111; Caso Palamara Iribarne Vs. Chile. Fondo, Reparaciones y Costas. Sentencia de 22 de noviembre de 2005. Serie C No 135.

73 Corte IDH. Caso Claude Reyes y otros Vs. Chile. Fondo, Reparaciones y Costas. Sentencia de 19 de septiembre de 2006. Serie $C \mathrm{~N}^{\circ} 151$.

74 Corte IDH. Caso Villagrán Morales y otros vs. Guatemala y Caso Instituto de Rehabilitación del Menor "Panchito López" vs. Paraguay. Excepciones Preliminares, Fondo, Reparaciones y Costas. Sentencia de 2 de septiembre de 2004. Serie C $\mathrm{N}^{\mathrm{o}} 112$.

75 Corte IDH. Caso Ximenes Lopes vs. Brasil. Sentencia de 4 de julio de 2006. Fondo, Reparaciones y Costas. Serie C $\mathrm{N}^{\circ} 149$.

76 Corte IDH. Caso Albán Cornejo y otros. Vs. Ecuador. Fondo, Reparaciones y Costas. Sentencia de 22 de noviembre de 2007. Serie C No 171. 
al ejecutado como víctima ${ }^{77}$. Conoció, por lo tanto, del retardo injustificado de la administración de justicia para investigar el caso, la obstrucción del proceso judicial por agentes que actuaron bajo la cobertura de una función pública, y la aplicación de normas incompatibles con el objeto y fin de la Convención Americana, todo lo cual había ocurrido después del reconocimiento de la jurisdicción por Nicaragua y decidió que se había producido una violación del artículo 8.1 de la Convención ${ }^{78}$ en perjuicio de Raymond Genie Peñalba, padre del hijo asesinado ${ }^{79}$. De esta manera, la Corte aplicó las normas del debido proceso en un proceso penal a alguien que no era el acusado sino el acusador, sin fundamentar las razones jurídicas de la fuente internacional de la que se podía desprender el derecho que tenía el afectado para ser oído ante el tribunal ${ }^{80}$. Se dio así una modalidad que introdujo el tema de terceros que podían tomar parte en el proceso penal y se asoció este derecho al derecho a la verdad que tienen ciertos familiares de las víctimas y a una manera de reparar a las víctimas. Un ejemplo claro es la sentencia de Gómez Paquiyauri, donde la Corte señaló que: "La Corte considera que las víctimas de graves violaciones de derechos humanos y sus familiares, en su caso, tienen el derecho a conocer la verdad [...] Este derecho a la verdad ha venido siendo desarrollado por el Derecho Internacional de los Derechos Humanos; [...] al ser reconocido y ejercido en una situación concreta, ello constituye un medio importante de reparación" ${ }^{\prime 11}$. En frecuentes ocasiones, la Corte también ha sostenido que este derecho a la verdad es de la sociedad entera ${ }^{82}$.

El caso Blake tuvo un problema de incompetencia ratione temporis similar al del caso Genie Lacayo. La Corte decidió en su sentencia que se había violado en perjuicio de los familiares del desaparecido el artículo 8.1 de la Convención, fundamentándose en la necesidad de hacer una interpretación amplia del artículo 8.1, en el que estaba comprendido también el derecho de los familiares de la víctima a las garantías judiciales, por cuanto "todo acto de desaparición forzada sustrae a la víctima de la protección de la ley y le causa graves sufrimientos, lo mismo que a su familia" tal como se establecía en la Declaración de Naciones Unidas sobre la Protección de Todas las Personas contra las Desapariciones Forzadas artículo $1.2^{83}$.

En el caso Garrido y Baigorria y posteriormente en el de Paniagua Morales ${ }^{84}$, por el contrario, se avanzó una tesis que no ha sido explorada con claridad por la Corte. En la sentencia de reparaciones de Garrido, la Corte sostuvo que:

La obligación de garantía y efectividad es autónoma y distinta de la de reparación. La razón de esta diferencia se manifiesta en lo siguiente: la reparación prevista en el artículo 63.1, tiende a borrar las consecuencias que el acto ilícito pudo provocar en la persona afectada o en sus familiares o allegados. Dado que se trata de una medida dirigida a reparar una situación personal, el afectado

77 Corte IDH. Caso Genie Lacayo Vs. Nicaragua. Excepciones Preliminares. Sentencia de 27 de enero de 1995. Serie C № 21, párr. 21.

78 El artículo 8.1 prescribe: "1. Toda persona tiene derecho a ser oída, con las debidas garantías y dentro de un plazo razonable, por un juez o tribunal competente, independiente e imparcial, establecido con anterioridad por la ley, en la sustanciación de cualquier acusación penal formulada contra ella, o para la determinación de sus derechos y obligaciones de orden civil, laboral, fiscal o de cualquier otro carácter".

79 Corte IDH, Caso Genie Lacayo Vs. Nicaragua. Fondo, Reparaciones y Costas. Sentencia del 29 de enero de 1997. Serie C $\mathrm{N}^{\circ} 30$, parrs. 97 y 2 .

80 Ibídem, párr. 75.

81 Corte IDH, Caso Hermanos Gómez Paquiyauri vs. Perú, párr. 230.

82 Ver ibídem, párr. 231. Ver también Caso de la Masacre de la Rochela, párr. 295.

83 Corte IDH, Caso Blake Vs. Guatemala. Fondo. Sentencia de 24 de enero de 1998. Serie C No 36, párr. 97.

84 Corte IDH, Caso Garrido y Baigorria Vs. Argentina. Fondo. Sentencia de 2 de febrero de 1996. Serie C No 26; Caso de la "Panel Blanca" (Paniagua Morales y otros) Vs. Guatemala. Fondo. Sentencia de 8 de marzo de 1998. Serie C No 37, párr. 99. 
puede renunciar a ella. [...] En cambio, aun cuando el particular damnificado perdone al autor de la violación de sus derechos humanos, el Estado está obligado a sancionarlo, salvo la hipótesis de un delito perseguible a instancia de un particular. La obligación del Estado de investigar los hechos y sancionar a los culpables no tiende a borrar las consecuencias del acto ilícito en la persona afectada, sino que persigue que cada Estado Parte asegure en su orden jurídico los derechos y libertades consagrados en la Convención ${ }^{85}$.

La decisión tomada en Garrido y Baigorria debería llevar a la Corte a concluir que no es necesario identificar a una víctima para exigir al Estado a que investigue. Esa posición traería quizás otras complicaciones, como la de supervisar que el Estado cumpla esta decisión sin tener personas determinadas que estén en el proceso. Comoquiera que sea, la modalidad de encontrar víctimas de la violación del artículo 8 ha permanecido hasta hoy. Con posterioridad al caso Génie Lacayo, la Corte conoció de la desaparición del señor Castillo Páez y allí no declaró violado el artículo 8, sino el artículo 25 de la Convención, por la ineficacia del recurso de habeas corpus, que era imputable al Estado ${ }^{86}$. Desde hace muchos años, la violación de la obligación de investigar se ha equiparado a una violación de los artículos 8, 25 y 1.1, este último referido a la obligación de garantizar en general.

En el caso Valle Jaramillo se dijo claramente que "del artículo 8 de la Convención se desprende que las víctimas de las violaciones de los derechos humanos, o sus familiares, deben contar con amplias posibilidades de ser oídos y actuar en los respectivos procesos [ $\left.{ }^{87}\right]$, tanto en procura del esclarecimiento de los hechos y del castigo de los responsables, como en busca de una debida reparación" citando allí jurisprudencia anterior ${ }^{88}$. Recientemente, sin embargo, se ha empezado a agregar como su fundamento el mismo derecho interno de los países. Se vio ya en el caso García Prieto ${ }^{89}$, donde se estableció que "la obligación de investigar no sólo se desprende de las normas convencionales de Derecho Internacional imperativas para los Estados Partes, sino que además se deriva de la legislación interna que haga referencia al deber de investigar de oficio ciertas conductas ilícitas y a las normas que permiten que las víctimas o sus familiares denuncien o presenten querellas para participar procesalmente en la investigación penal con la pretensión de establecer la verdad de los hechos". Esto se ha repetido posteriormente en el caso Heliodoro Portugal y en el caso Valle Jaramillo ${ }^{90}$.

A lo largo de los años, la Corte ha desarrollado esta idea y claramente ha conferido a los familiares de la víctima de ciertas violaciones el derecho a exigir del Estado una investigación penal en la que pueden participar. En el caso Goiburu, la Corte recordó que "los familiares de las víctimas tienen el derecho, y los Estados la obligación, a que lo sucedido a aquéllas sea efectivamente investigado por las autoridades del Estado, se siga un proceso contra los presuntos responsables de estos ilícitos y, en su caso, se les impongan las sanciones pertinentes" ${ }^{\prime 1}$.

\footnotetext{
85 Corte IDH, Caso Garrido y Baigorria Vs. Argentina. Sentencia de 27 de agosto de 1998. Reparaciones. Serie C. № 39, párr. 72.

86 Corte IDH, Caso Castillo Paez Vs. Peru. Sentencia de 23 de noviembre de 1997. Fondo. Serie C No 34, párrs. 79 y 84.

87 Ver, para una posición contraria, mis votos, inter alia, en Corte IDH, Caso 19 Comerciantes, Caso Gómez Paquiyauri, y en Caso Gómez Palomino Vs. Perú. Fondo, Reparaciones y Costas. Sentencia de 22 de noviembre de 2005. Serie C № 136.

88 Caso Valle Jaramillo, párr. 102, citando allí jurisprudencia.

89 Corte IDH, Caso García Prieto Vs. El Salvador. Excepción preliminar, Fondo, Reparaciones y Costas. Sentencia de 20 de noviembre de 2007, Serie C No 168, párrs. 102-104.

90 Caso Heliodoro Portugal, párr. 143, y Caso Valle Jaramillo Vs. Colombia, párr. 104.

91 Caso Goiburu Vs. Paraguay, párr. 165.
} 


\section{d. Artículo 5 de la Convención. La calidad de víctimas de ciertos familiares}

En el caso Blake, donde se dijo anteriormente que la Corte no había conocido de la violación del derecho a la vida por falta de competencia ratione temporis, la Corte sostuvo que se había violado en perjuicio de ciertos familiares el artículo 5, básicamente porque "las circunstancias de dicha desaparición generan sufrimiento y angustia, además de un sentimiento de inseguridad, frustración e impotencia ante la abstención de las autoridades públicas de investigar los hechos"92. Hasta ese entonces, aun cuando permanentemente la Corte había hecho mención de la angustia y sufrimiento generados por la desaparición de un familiar y por la ausencia de respuesta estatal, nunca había calificado a estos familiares como víctimas de una violación de su integridad personal. Con este caso, la Corte empezó a tomar esto en consideración y a calificarlos como titulares de una reparación por la violación de sus propios derechos ${ }^{93}$.

En el transcurso de estos años, podría decirse que, a pesar de algunos vaivenes ${ }^{94}$, hay una jurisprudencia relativamente asentada, en el sentido de que para decidir la calidad de víctima de ciertos familiares hay que examinar la proximidad del vínculo familiar; las circunstancias particulares del familiar en cuanto a su relación con la víctima; el tipo de violación -puesto que, en general, toda violación a un derecho humano de una persona puede causar algún sufrimiento o desazón a ciertos familiares de la víctima, pero eso no puede ser causal suficiente para decidir que se ha violado también la integridad personal de éstos-; la vinculación del familiar con las persecución de la verdad y la justicia y la afectación del mismo por la negligencia o la inacción voluntaria del Estado en el proceso judicial. Normalmente, pero no estrictamente en todos los casos, se presume que los padres y los hijos reúnen estos requisitos cuando ha habido una desaparición, una ejecución extrajudicial o tortura, todas ellas en un contexto de violaciones masivas y sistemáticas ${ }^{95}$.

92 Caso Blake, párr. 114.

93 Para un tratamiento más detallado de la situación de los familiares, ver MEDINA, C. "La Corte Interamericana de Derechos Humanos y los familiares de las víctimas". En: FERRER, E. y ZALDÍVAR, A. (coord.). La Ciencia del Derecho Procesal Constitucional. Estudios en Homenaje a Héctor Fix-Zamudio en sus Cincuenta Años como Investigador del Derecho, T. IX, Derechos Humanos y Tribunales Internacionales. México, Instituto de Investigaciones Jurídicas de la UNAM. 2008, pp. 545 a 571. Texto en www.jurídicas.unam.mx

94 Corte IDH, Caso de los "Niños de la Calle" (Villagrán Morales y otros) Vs. Guatemala. Fondo. Sentencia de 19 de noviembre de 1999. Serie C No 63; Caso Trujillo Oroza Vs. Bolivia. Fondo. Sentencia de 26 de enero de 2000. Serie C № 64; Caso Juan Humberto Sánchez Vs. Honduras. Excepciones Preliminares, Fondo, Reparaciones y Costas. Sentencia de 7 de junio de 2003. Serie C No 99; Caso Myrna Mack Chang Vs. Guatemala. Fondo, Reparaciones y Costas. Sentencia de 25 de noviembre de 2003. Serie C No 101; Caso Molina Theissen Vs. Guatemala. Fondo. Sentencia de 4 de mayo de 2004. Serie C No 106; Caso 19 Comerciantes Vs. Colombia. Fondo, Reparaciones y Costas. Sentencia de 5 de julio de 2004. Serie $C N^{\circ} 109$, entre otras.

95 Corte IDH, Caso de las Hermanas Serrano Cruz Vs. El Salvador. Fondo, Reparaciones y Costas. Sentencia de 1 de marzo de 2005. Serie C No 120; Caso de la "Masacre de Mapiripán" Vs. Colombia. Excepciones Preliminares. Sentencia de 7 de marzo de 2005. Serie C No 122; Caso Gómez Palomino Vs. Perú. Fondo, Reparaciones y Costas. Sentencia de 22 de noviembre de 2005. Serie C No 136; Caso Blanco Romero y otros Vs. Venezuela. Fondo, Reparaciones y Costas. Sentencia de 28 de noviembre de 2005. Serie C N ${ }^{\circ}$ 138; Caso de la Masacre de Pueblo Bello Vs. Colombia. Fondo, Reparaciones y Costas. Sentencia de 31 de enero de 2006. Serie C № 140; Caso Baldeón García Vs. Perú. Fondo, Reparaciones y Costas. Sentencia de 6 de abril de 2006. Serie C No 147; Caso La Cantuta Vs. Perú. Fondo, Reparaciones y Costas. Sentencia de 29 de noviembre de 2006. Serie C No 162; Caso de la Masacre de La Rochela, nota 58; Caso Heliodoro Portugal Vs. Panamá, nota 50; y Caso Ticona Estrada Vs. Bolivia. Fondo, Reparaciones y Costas. Sentencia de 27 de noviembre de 2008. Serie C No 191 .

Corte IDH, Caso Genie Lacayo Vs. Nicaragua. Fondo, Reparaciones y Costas. Sentencia del 29 de enero de 1997. Serie C № 30; Caso Blake Vs. Guatemala. Fondo. Sentencia de 24 de enero de 1998. Serie C No 36; Caso Durand y Ugarte Vs. Perú. Fondo. Sentencia de 16 de agosto de 2000. Serie C No 68, párrs. 130 y 131; Caso Bámaca Velásquez Vs. Guatemala. Fondo. Sentencia de 25 de noviembre de 2000. Serie C No 70; supra nota 41, párr. 201 y 196; Caso Barrios Altos Vs. Perú. Fondo. Sentencia de 14 de marzo de 2001. Serie C Nº 75, párr. 48; y Caso Juan Humberto Sánchez Vs. Honduras. Excepciones Preliminares, Fondo, Reparaciones y Costas. Sentencia de 7 de junio de 2003. Serie C No 99, párr. 136. 


\section{El impacto de la jurisprudencia de la Corte en la región}

Los perjudicados por un incumplimiento de obligaciones internacionales por parte de un Estado no pueden, a diferencia de lo que sucede en el derecho internacional público clásico, recurrir a las represalias o a la institución del do ut des que es lo que permite asegurar un cumplimiento relativamente importante de las obligaciones internacionales en otros campos. Las víctimas de violaciones de derechos humanos no están en una situación de igualdad con el Estado como lo están los Estados entre sí, aunque ésta sea ficticia en la realidad. Dependen completamente del Estado para que éste cumpla con su deber internacional. Esa es la razón de haber creado un sistema interamericano de protección para defenderlas. El sistema interamericano, el europeo o el del Pacto Internacional de Derechos Civiles y Políticos de las Naciones Unidas se basan en la idea de que las normas internacionales de los tratados de derechos humanos constituyen un orden público internacional que los Estados están en el deber de mantener. Es por esto que todos los tratados permiten que un Estado denuncie las violaciones cometidas por otro Estado ${ }^{96}$.

Aun así, el sistema, sin embargo, dista mucho de ser perfecto. La Corte dicta sentencias que son jurídicamente vinculantes, pero sólo la parte indemnizatoria de la sentencia puede ejecutarse dentro del Estado, en cumplimiento del artículo 68 de la Convención. Existe en la Convención una disposición, el artículo 65, que ordena a la Corte someter a la consideración de la Asamblea General de la OEA un informe sobre su labor en el año anterior y le exige que señale los casos en que un Estado no ha dado cumplimiento a sus fallos y que dé "las recomendaciones pertinentes". Obviamente, esa disposición debe tener algún sentido, ya que una norma básica de interpretación es que toda norma debe ser leída de modo que produzca un efecto útil. El efecto, estimo, debería ser la intervención de la Asamblea dentro del campo de sus acciones políticas para estimular el cumplimiento, o para condenarlo. Nada de esto sucede en la práctica.

La falencia en el actuar de la Organización deja a las víctimas desprovistas de un apoyo que podría ser extremadamente importante y la Corte ha tratado de paliar esta falla desarrollando la idea de la supervisión del cumplimiento de las sentencias a través de la petición de informes periódicos a los Estados, los que a su vez son comentados por las víctimas y por la Comisión. En 2007 la Corte dio un paso más y agregó una nueva forma de supervisión a través de audiencias privadas con el Estado, la víctima y la Comisión para conversar sobre las dificultades que ha tenido el Estado para el cumplimiento de lo ordenado por la Corte. Estas audiencias han sido bienvenidas por todas las partes y han dado lugar a progresos que quizás no se habrían alcanzado de otra manera.

Afortunadamente, el derecho internacional de los derechos humanos ha ganado una gran legitimidad y ha empezado a permear la sociedad civil en el continente. El cumplimiento de las sentencias de la Corte se ha vuelto más frecuente, con la excepción de la obligación de investigar, procesar y eventualmente condenar, que es la razón de que un significativo porcentaje de casos se encuentren aún abiertos.

Hay ya varios Estados en los que, ya sea a través de resoluciones de sus tribunales superiores ${ }^{97}$, o de su ordenamiento jurídico interno, han incorporado las sentencias de la Corte en un rango que, por una parte, permite su cumplimiento y, por otra, hace que se reconozcan como parámetro para decidir casos similares.

\footnotetext{
96 Ver CADH, artículo 61; Pacto Internacional de Derechos Civiles y Políticos, artículo 41; Convenio Europeo para la Protección de los Derechos Humanos y de las Libertades Fundamentales, artículo 33.

97 Un estudio de la interacción entre la Corte y los tribunales internos puede encontrarse en GARCÍA-SAYÁN, D. Una viva interacción: Corte Interamericana y Tribunales Internos. En: Corte IDH. La Corte Interamericana de Derechos Humanos. Un Cuarto de Siglo: 1979-2004. San José de Costa Rica. Corte IDH. 2005, pp. 323-384.
} 
De todos los Estados Partes de la Convención que han reconocido la competencia jurisdiccional de la Corte, el que más pronto lo hizo fue Costa Rica, que estableció en su acuerdo de sede con la Corte que las resoluciones de la Corte y de su Presidente, en su caso, tendrían la misma fuerza ejecutiva y ejecutoria que las dictadas por los tribunales costarricenses ${ }^{98}$. La Sala Constitucional de la Corte Suprema ha ampliado esto, incluyendo ahí incluso las opiniones consultivas de la Corte $^{99}$.

En Colombia, la Constitución Política de 1993 reconoce en su artículo 93 que:

"Los tratados y convenios internacionales ratificados por el Congreso, que reconocen los derechos humanos y que prohíben su limitación en los estados de excepción, prevalecen en el orden interno.

Los derechos y deberes consagrados en esta Carta, se interpretarán de conformidad con los tratados internacionales sobre derechos humanos ratificados por Colombia".

Interpretando esta norma, el Tribunal Constitucional colombiano ha incluido la jurisprudencia de la Corte Interamericana en su bloque de constitucionalidad, por lo cual las sentencias de esta Corte sirven de parámetro para examinar los casos de que se conozca en la legislación interna ${ }^{100}$. Esta posición parece lógica, ya que si la Constitución debe interpretarse de conformidad con los tratados de derechos humanos y la Convención Americana, que es uno de ellos, tiene a la Corte Interamericana como única autoridad con la facultad de interpretarla, la conclusión ineludible es que las sentencias de la Corte deben ser cumplidas por el Estado colombiano y tomadas en consideración para todos los $\operatorname{casos}^{101}$.

En Argentina, el artículo 75, inciso 22 de la Constitución Política de 1994 establece la jerarquía constitucional de los tratados de derechos humanos. La Corte Suprema argentina ha establecido que los fallos de la Corte son obligatorios ${ }^{102}$ y han sido aplicadas consistentemente para enfrentar los casos de la época de la dictadura en Argentina ${ }^{103}$. En el caso Simón, reiteró en su considerando 17) que la jurisprudencia de la Corte era "imprescindible pauta de interpretación de los deberes y obligaciones derivados de la Convención Americana sobre Derechos Humanos". La posición de la Corte Suprema argentina se ha reproducido en provincias ${ }^{104}$.

El Tribunal Constitucional de Bolivia declaró "que los instrumentos internacionales en materia de derechos humanos son parte del bloque de constitucionalidad, así como la jurisprudencia

98 Convenio de Sede entre el Gobierno de la República de Costa Rica y la Corte Interamericana de Derechos Humanos, 10 de septiembre de1981.

99 PIZA ESCALANTE, R. El valor del derecho y la jurisprudencia internacionales en el derecho y la justicia internos - El ejemplo de Costa Rica. En: Corte IDH. Liber Amicorum Héctor Fix-Zamudio. San José, Costa Rica. 1998, Vol. I, pp. 169-191.

100 Tribunal Constitucional de Colombia, Sentencia C-355/06. En dicha sentencia se citan también, por el Procurador General de la Nación, las sentencias C-010 de 2000, C-04 de 2003; y T-453 de 2005. (Ver párr. 6.2 de su presentación ante la Corte).

101 Sobre este punto, ver UPRIMNY, R. Bloque de constitucionalidad. Derechos Humanos y Proceso Penal. Consejo Superior de la Judicatura, Sala Administrativa, Escuela Judicial "Rodrigo Lara Bonilla", Colombia, 2006, particularmente pp. 70 y 71.

102 Corte Suprema de Argentina, Caso Ekmekdjian, Miguel, A. C. Sofovich, Gerardo y otros. Sentencia de 7 de julio de 1992.

103 Corte Suprema de la Nación Argentina, Recurso de hecho en la causa N ${ }^{\circ}$ 17.768, Simón, Julio Héctor y otros s/ privación de libertad. Sentencia de 14 de junio de 2005. Ver también Fallo 315: 1492, sentencia de 13 de julio de 2007 en la Causa Mazzeo, Julio Lillo y otros/ recurso de casación e inconstitucionalidad.

${ }^{104}$ Cámara del Tribunal Oral en lo Criminal Federal de Tucumán, Causa: "Vargas Aignasse Guillermo S/Secuestro y Desaparición".- Expte. V - 03/08, sentencia dictada el día veintiocho de agosto del corriente año, condenando a Antonio Bussi, ex Gobernador de Tucumán, Argentina. 
emanada del sistema interamericano de protección a los derechos humanos es vinculante para la jurisdicción interna de Bolivia"105.

Independientemente de si la jurisprudencia de la Corte está o no incorporada en un bloque de constitucionalidad, como quiera que éste se denomine, hay ya variadas sentencias de Estados de la región que han utilizado la jurisprudencia para decidir causas que digan relación con las violaciones del pasado. Esto se ha aplicado aun en causas que no dicen relación con violaciones en un contexto de violaciones masivas y sistemáticas: en Paraguay, por ejemplo, un Juzgado de Asunción acogió un amparo ${ }^{106}$, apoyándose para ello en la sentencia Claude Reyes vs. Chile sobre acceso a la información ${ }^{107}$. En Chile, el fallo de la Corte sobre la Última Tentación de Cristo ${ }^{108}$ fue un impulso importante para la enmienda del artículo $19^{\circ} 12$ de la Constitución Política, eliminándose la censura cinematográfica. El caso Claude Reyes dio también lugar a capacitaciones de funcionarios públicos sobre acceso a la información y jugó un papel en la dictación de la Ley N² 20.285, "Ley de Transparencia de la Función Pública y Acceso a la Información de la Administración del Estado". En la resolución de supervisión de cumplimiento de sentencia, la Corte señala que el Estado destacó la extraordinaria contribución de la sentencia para el fortalecimiento de la libertad de expresión, en lo que las víctimas estuvieron también de acuerdo ${ }^{109}$.

\section{Conclusiones}

El examen por la Corte de violaciones específicas sucedidas en un contexto de violaciones masivas y sistemáticas producto de la represión estatal por razones políticas ha originado, como pudo observarse, una línea de interpretación importante en torno a la obligación de garantizar el goce de los derechos humanos, incorporando en ella las obligaciones de prevenir y de investigar, procesar y eventualmente condenar, obligación que perdura en el tiempo y que da a la Corte el poder de asumir su jurisdicción contenciosa aun en casos cuya ejecución ha precedido a la declaración de aceptación de esta jurisdicción por el Estado respectivo. La subsistencia de la obligación ha causado también la prohibición de utilizar leyes de amnistía, la prescripción o cualquier otro instituto que permita dejar estas severas violaciones en la impunidad.

Ha habido además un desarrollo amplio del artículo 8 y del artículo 25 de la Convención, que han sido usados como fundamento del derecho de los familiares de las víctimas de desapariciones y ejecuciones sumarias, además de las víctimas de tortura, para exigir una investigación criminal en la cual tienen derecho a participar de diversas maneras. Ambos artículos configurarían el "acceso a la justicia" y el "derecho a la verdad" -que se invoca frecuentemente por los familiares de las víctimas de estos casos y también por la Comisión- los que tendrían su fuente en ellos ${ }^{110}$.

105 Citada en Corte IDH, Caso Ticona Estrada vs. Bolivia. Sentencia de 27 de noviembre de 2008. Fondo Reparaciones y Costas. Serie C No 192, párr. 147.

106 Juzgado de Liquidación y Sentencia N ${ }^{\circ} 1$ de Asunción, Recurso de amparo de Elizabeth Flores Negri contra Rectorado de la Universidad Nacional de Asunción, sentencia S.D. № 40 de 31 julio de 2007.

107 Corte IDH, Caso Claude Reyes y otros vs. Chile. Sentencia de 19 de septiembre de 2006. Fondo, Reparaciones y Costas. Serie C N 151 .

${ }^{108}$ Corte IDH, Caso Olmedo y otros vs. Chile, Sentencia de 5 de febrero de 2001. Fondo. Serie C N 73.

${ }^{109}$ Corte IDH, Caso Claude Reyes y otros vs. Chile, Resolución de supervisión de cumplimiento de 28 de noviembre de 2008, párrafos 10 y 11.

${ }^{110}$ Corte IDH, Caso Genie Lacayo Vs. Nicaragua. Fondo, Reparaciones y Costas. Sentencia del 29 de enero de 1997. Serie C No 30; Caso Blake Vs. Guatemala. Fondo. Sentencia de 24 de enero de 1998. Serie C No 36; Caso Durand y Ugarte Vs. Perú. Fondo. Sentencia de 16 de agosto de 2000. Serie C Nº 68, párrs. 130 y 131; Caso Bámaca Velásquez Vs. Guatemala. Fondo. Sentencia de 25 de noviembre de 2000. Serie C No 70; párr. 201 y 196, Caso Barrios Altos Vs. Perú. Fondo. Sentencia de 14 de marzo de 2001. Serie C № 75, párr. 48; y Caso Juan Humberto Sánchez Vs. Honduras. Excepciones Preliminares, Fondo, Reparaciones y Costas. Sentencia de 7 de junio de 2003. Serie C No 99, párr. 136. 
Finalmente ha dado la categoría de víctimas a ciertos familiares que han sufrido a consecuencia de ciertas violaciones de miembros de su familia y se han enfrentado en esos casos con la completa inactividad o derechamente con la obstaculización por parte del Estado de sus legítimas demandas de justicia.

Lo reseñado respecto al impacto en la región parece ser suficiente para concluir que la Corte ha logrado su objetivo de dar respuesta al clamor de justicia de tantos seres humanos del continente víctimas de violaciones masivas y sistemáticas producto de la represión política en tiempos de dictadura, sentando, además, las bases para el desarrollo de la especificación de las obligaciones que la Convención establece para el goce de todos los derechos humanos. 